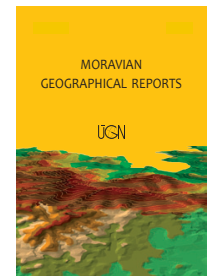

MORAVIAN GEOGRAPHICAL REPORTS

\title{
The effects of river patterns on riparian vegetation: A comparison of anabranching and single-thread incised channels
}

\author{
Václav ŠKARPICH ${ }^{\text {* }}$, Matěj HORÁČEK ${ }^{\text {a }}$, Tomáš GALIA ${ }^{\mathrm{a}}$, \\ Veronika KAPUSTOVÁ a , Vladimír ŠALA ${ }^{\text {b }}$
}

\begin{abstract}
Riparian vegetation reflects the current conditions and the dynamics of streams. The floodplain vegetation along the watercourse of the Morávka River was subject to study in this project. In some reaches, the river has the natural character of an anabranching gravel-bed stream; in contrast, other Morávka R. reaches are incised into the bedrock. These cases were used to assess potential changes in vegetation conditions as evidence of negative processes taking place in the gravel-bed streams of the Beskydy Mts. The results demonstrate a higher biodiversity in the floodplain along the anabranching river channel. In contrast, the floodplain along the incised river channel shows low biodiversity values. Redundancy analysis was used to determine the relationships between plant species composition, distance from the main channel and relative elevation from the mean water level of the main channel. In addition, the results show a higher degree of change in plant species composition on the floodplain along the incised river channel. The analysis of floodplain groundwater fluctuations shows a decreasing trend in the annual maximum groundwater level.
\end{abstract}

Key words: riparian vegetation, channel pattern, phytosociological survey, multivariate data analysis, the Morávka River, Outer Western Carpathians, Czech Republic

Article history: Received 28 May 2015; Accepted 2 June 2016; Published 30 September 2016

\section{Introduction}

Natural river landscapes represent one of the richest ecosystems in temperate zones (Forman and Godron, 1986). They are characterised by a unique combination of aquatic and terrestrial components, a mosaic of habitats and high biodiversity (Xiao et al., 2003). Erosion naturally occurs in all parts of the drainage pattern but, generally, river systems could be characterised by erosion in the uplands, downstream sediment transport and storage in the lowlands (Kondolf, 1997; Knighton, 1998). Complex environmental conditions, induced by geology, climate, hydrology and the morphology of channels and floodplain, affect the growth of vegetation in the fluvial landscape ecosystems (Králová, 2001). Vegetation classification based on the environmental conditions is one of the integral parts of landscape management and landscape research. A majority of these classifications is based especially on the water régime. Other factors are temperature (based on altitude) and trophic condition: see, for example, Plíva and
Průša (1969) and Hančinský (1977) in the Czech Republic, Schönhar (1993) in Germany, or Hills (1966) in Canada.

These key factors also destroy, modify and build habitats and the associated riparian vegetation of river systems and influence disturbances important for the development of the floodplain environment (Naiman et al., 2005; Steiger et al., 2005; Tabacchi et al., 1998). Thus, vegetation is a good indicator of the present state of the environment, integrating diverse environmental influences and events that occurred in the past (Prach, 1994). An additional important factor is the effect of ground water, which affects the vegetation by its height levels, régime and quality (e.g. acidity, alkalinity or content of minerals.). This is one of the essential factors for the evaluation of changes in vegetation communities (Šeffer and Stanová, 1999).

Corridors of riparian vegetation along watercourses play an irreplaceable role in the landscape. They prevent flooding and bank erosion, and supply nutrients to habitats

\footnotetext{
a Department of Physical Geography and Geoecology, Faculty of Science, University of Ostrava, Ostrava, Czech Republic (*corresponding author: V. Škarpich; e-mail: vaclav.skarpich@osu.cz)

${ }^{\mathrm{b}}$ Czech Hydrometeorological Institute - Ostrava Branch, Ostrava, Czech Republic
} 
(Forman and Godron, 1986). In the case of changes in environmental conditions (e.g. alterations of water régime in the landscape, such as discharge régime changes or change of groundwater level connected with river channel incision or the elimination of flood flows), one can expect a change in the riparian vegetation, termed ecological succession. Ecological succession is an observed process of change in the species structure of an ecological community over time. The community begins with relatively few pioneer plants and develops through increasing complexity until it becomes stable or self-perpetuating as a climax community (Glenn and Lewin et al., 1992; Walker and Del Moral, 2003).

This article presents the results of our study of the riparian vegetation in the Morávka River floodplain area. The Morávka $R$. has experienced a rapid change in the last 50 years, when its active channel narrowed and massive incision took place. At present, the study area is characterised by two distinctive reaches of different development away from the originally anabranching gravel-carrying stream. The lower reach $(0-7.0 \mathrm{r} . \mathrm{km}$, see Fig. 1$)$ is strongly affected by incision, but the upper reach (7.0-10.5 r. km, see Fig. 1) has partly preserved the original anabranching river pattern with lateral channel-migration. The main reasons for the massive incision of the lower reach $(0-7.0 \mathrm{r} . \mathrm{km})$ are strong anthropogenic impacts, namely river-channel control, bank stabilisation, and weir and valley dam construction (Galia et al., 2016; Škarpich et al., 2013; 2016). At 0-7.0 r. km, the anabranching channel pattern of the Morávka R. started to transform into a single-thread channel in the 1960s (the anabranching channel pattern is still visible in the aerial photograph from 1966, see Škarpich et al., 2013). The channel development has been influenced especially by the so-called Frýdek weir (at $1.25 \mathrm{r} . \mathrm{km}$ ) and by the Konečný weir (at $2.31 \mathrm{r.km}$ ). Firstly, these weirs affected hydraulic conditions and the 'hungry water effect' (the term sensu Kondolf, 1997), which turned into incision downstream of these structures, as shown by observations and measurements (see Škarpich et al., 2013). Later, both weirs were destroyed by floods (the first one in 1949, the latter in the mid-1970s), and the river channel was gradually incised by upstream knickpoint retreat (for more detailed information see Škarpich et al., 2016). One important influence in the contemporary occurrence of the preserved original anabranching river pattern $(7.0-10.5 \mathrm{r} . \mathrm{km})$ is to a certain extent the Těšín-Hradiště Formation. This structural formation is represented by sandstone layers in the channel bedrock. These sandstone layers are more resistant to knickpoint propagation from the deeply incised reach. For more detailed analyses of channel changes in the Morávka River basin - see Škarpich et al. (2013) and Galia et al. (2016).

This paper provides an analysis of vegetation communities along two clearly contrasted river reaches (single-thread and anabranching channel patterns) based on a simple biodiversity assessment. The entire analysis was conducted on two transects (one in each of the contrasting river pattern settings), each with five data-points (compare to Solon et al., 2007). The main hypothesis is that channel incision processes are followed by a shift in environmental conditions (connected with the water regime in the landscape), which is reflected in a subsequent riparian vegetation change. The intense and temporally varying disturbances in the Morávka $\mathrm{R}$. basin are continuously adjusting to new constraints of the floodplain environment. River incision eliminated the floodplain function and the periodical river inundation ceased to exist. These changes had to influence the plant species composition in the floodplain area. The main aim of this paper, then, is to analyse and compare environmental conditions and the distribution of plant species in the floodplain area along the respective river-channel patterns.

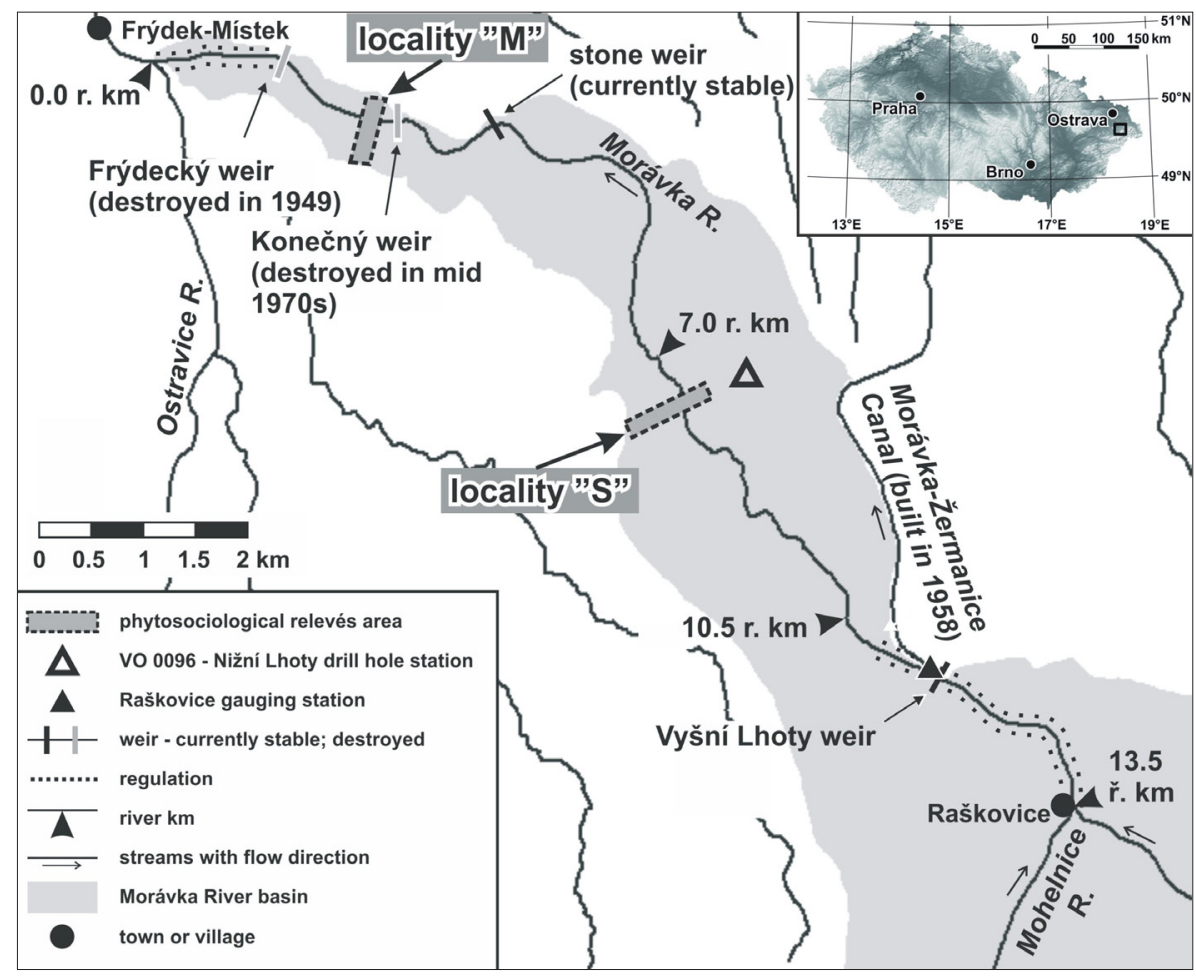

Fig. 1: Scheme of the lower Morávka R. basin with the location of analysed phytosociological relevés (transects) and water structures. Each transect shows approximate floodplain width in the analysed river reach

Source of data: T. G. Masaryk Water Research Institute; State Administration of Land Surveying and Cadastre; source: author's elaboration 


\section{Regional settings}

The Morávka River (see Fig. 1) is a gravel-bed stream $29.6 \mathrm{~km}$ in length that flows from the steep slopes of the Moravskoslezské Beskydy Mts. (MSB) to the flat piedmont. The annual precipitation in the basin ranges from 1,000 to $1,800 \mathrm{~mm}$ (data source: Czech Hydrometeorological Institute). The drainage area of the Morávka R. is $149 \mathrm{~km}^{2}$. The mean annual discharge of the river reaches $3.73 \mathrm{~m}^{3} \cdot \mathrm{s}^{-1}$ at the Raškovice gauging station (upstream from the study area; for the location see Fig. 1), where the basin area is $131 \mathrm{~km}^{2}$ (data source: Povodí Odry). The Morávka $R$. is characterised by the occurrence of frequent floods of moderate magnitude due to snow melting, and by the occurrence of rare heavy floods caused by cyclone-related summer rains. The study area is situated in the Podbeskydská Pahorkatina Hilly land built by the flysch Subsilesian and Silesian units of the Outer Group of Nappes (in the study area by the Upper Jurassic to Upper Cretaceous rocks) covered by Quaternary sediments (Menčík et al., 1983; Menčík and Tyráček, 1985; Picha et al., 2006). The flysch rocks of the Upper Jurassic to Cretaceous period belong in the Lower Těšín Member (prevailing silty-sandy and sandy claystones) and in the Tešín-Hradiště Formation (prevailing sandstones). The Upper Cretaceous rocks include the Frýdek Formation composed of calcareous shales and grey siltstones (Menčík et al., 1983; Picha et al., 2006).

The study area is part of the Western Carpathian subprovince - Podbeskydský bioregion (Culek, 2013). The dominant potential unit is represented by oak-hornbeam forests (Tilio cordatae-Carpinetum, Neuhäuslová et al., 1998; 2001). In the flat area around the town of FrýdekMístek, oak-beech forests occur (Carici-Quercetum, Neuhäuslová et al., 1998; 2001). Chokecherry-alder forests dominate (Pruno-Fraxinetum) in the floodplain areas and the gravel alluvium is covered by willow forests (Salicion eleagni) (Culek, 1996). The herb layer is relatively rich in species, given by numerous oreophytes from the Moravskoslezské Beskydy Mts. These are represented by Dentaria glandulosa Waldst. et Kit, Myricaria germanica (L.) Desv., Luzula luzulina (Vill.) Racib., Salix eleagnos Scop. or Hacquetia epipactis (Scop.) DC (Culek, 1996).

\section{Methods}

The research is based on a phytosociological survey. In simple terms, the phytosociological survey is a group of ecological evaluation methods providing a comprehensive overview of both the composition and distribution of plant species in a given plant community (Concenço et al., 2013). The phytosociological survey is based on the collection of data from phytosociological relevés. We evaluated the riparian vegetation in the lower part of the Morávka $R$. basin using phytosociological relevés sized $10 \times 10$ meters after Randuška et al. (1986). We collected the data during April and May 2014. Experimental plots were located through transversal profiles close to the river channel (see Fig. 1) in: (i) the single-thread bedrock-incised channel (5 relevés, Fig. 2A and Fig. 3A; locality "M"); and (ii) the

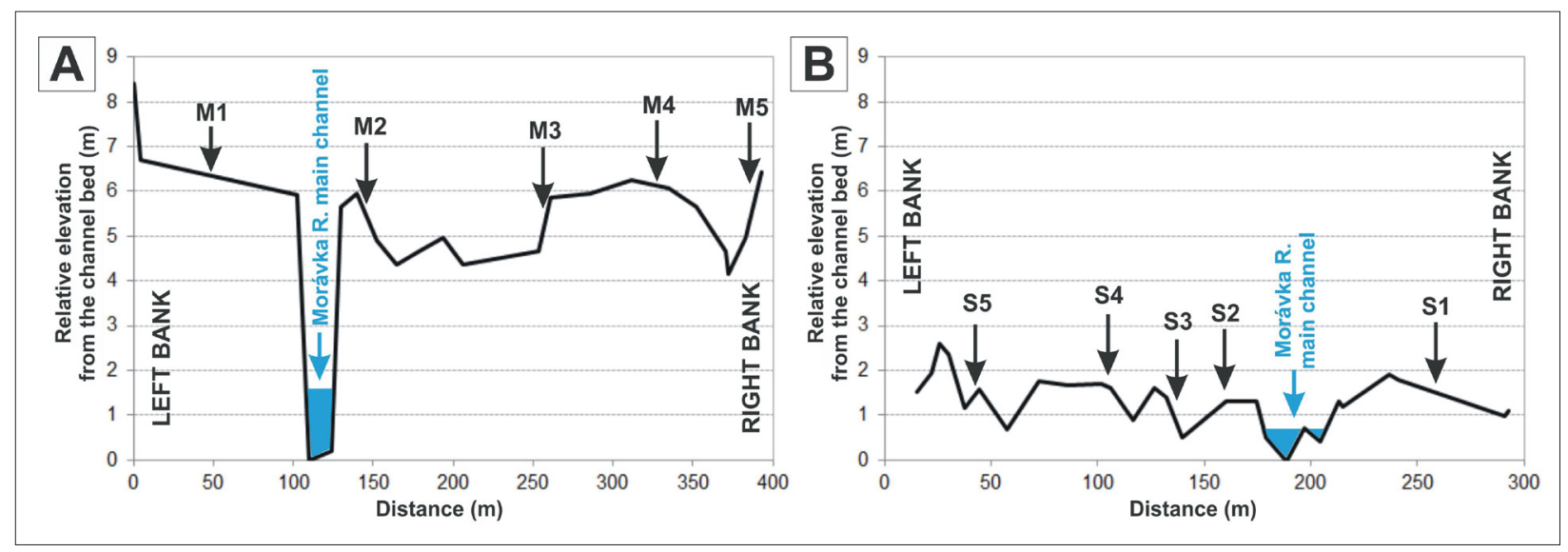

Fig. 2: Location of phytosociological relevés (M1-M5, S1-S5) in the cross section of the Morávka R. floodplain area: A - single-thread bedrock-incised channel; B - anabranching channel. Source: authors 'elaboration
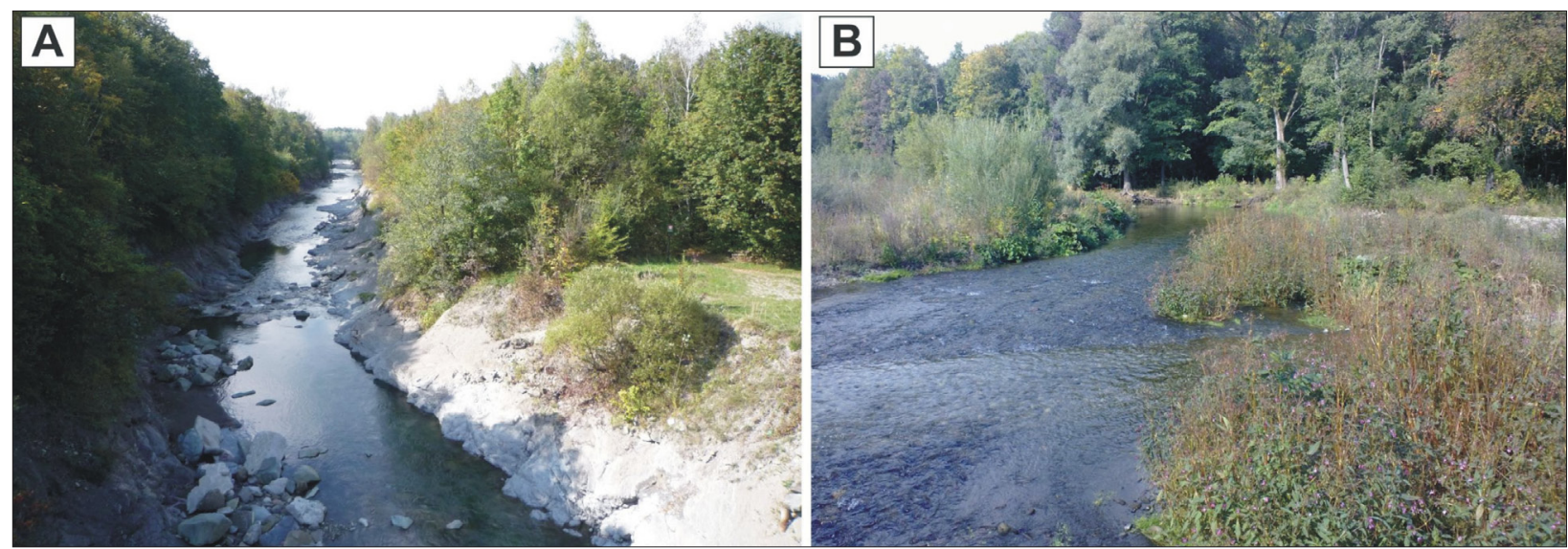

Fig. 3: The Morávka R.: A - single-thread bedrock-incised channel river; B - anabranching channel river reach Photo: V. Škarpich 
anabranching channel (5 relevés, Fig. $2 \mathrm{~B}$ and Fig. 3B; locality "S"). For the analysis, we collected data on the species composition in the herb layer.

We applied the Shannon-Wiener (Shannon and Weaver, 1949) and Simpson's (Simpson, 1949) indices of biodiversity for the analysis of species distribution. Both indices are quantitative measurements reflecting how many different species occur in a dataset, and simultaneously take into account how often the basic entities (such as individuals) are distributed among those types. The Shannon-Wiener index emphasises the richness component of diversity, while Simpson's index places emphasis on the evenness component (Shannon and Weaver, 1949, Simpson, 1949). Generally, the selection of the ShannonWiener index or Simpson's index can be problematic and both indices are commonly used for assessing biodiversity (Nagendra, 2002). Both indices can be very similar or, in very specific cases, they can show a considerable variation in response to changes in landscape richness and evenness (Nagendra, 2002). In this study, we used both indices to obtain stronger results.

Following Randuška et al. (1986), we transformed the data for each plant species from the ordinal phytosociological scale acquired to a quantitative phytosociological scale calculating the mean percentage coverages in each relevé. Firstly, the Shannon-Wiener Index was used to quantify the entropy, defined as:

$$
H=-\operatorname{sum}\left(p_{i} \ln p_{i}\right)
$$

where $p_{i}$ is the proportional abundance of species $\mathrm{i}$ (Shannon and Weaver, 1949). Secondly, the Simpson's Index (Simpson, 1949) was used to measure the degree of concentration when individuals are classified into types and it is defined as:

$$
\lambda=\operatorname{sum} p_{i}^{2} .
$$

For the statistical analysis we used the $\mathrm{R}$ software environment ( $R$ CORE TEAM, 2012) and the function package Vegan (Oksanen et al., 2013). For the ShannonWiener index calculation we applied the diversity () function with the following settings:

diversity (releve $N$, index = "shannon", MARGIN $=1$, base $=\exp (1)$ ),

and for the Simpson's index calculation we applied the diversity () function with the following settings:

diversity (releve $N$, index = "simpson", MARGIN =1, base $=\exp (1)$ ),

where releve_ $N$ is a given phytosociological relevé.

We evaluated the channel effects on the riparian vegetation conditions using multivariate data analysis. For this purpose, the phytosociological data were transformed into a logarithmic scale. The phytosociological data (as explanatory variables) include the percentage coverage of given plant species in the given phytosociological relevé. For the transformation, we used the logarithmic equation after Anderson et al. (2006) in order to increase the importance of rare species:

$$
x^{\prime}=\log _{2}(x)+1,
$$

where $x$ is the mean percentage coverage of a given plant species in a given relevé. In the context of the importance of vegetation response to channel-floodplain conditions, the following environmental variables were selected as response variables for the analysis: phytosociological relevé distance from the main channel with flowing water, and relative elevation of a phytosociological relevé from the water level in the main channel, where the main channel of anabranching pattern was considered to be the one containing the highest volume of water during the mean annual discharge. As a first step, detrended correspondence analysis (DCA) was carried out in order to determine the gradient length and thus to select a proper ordination method for further analyses. Gradient length shows the length of the first ordination axis in the n-dimensional space. The first ordination axis is defined in the space such that it reflects the maximum variability of the dataset (on this axis, a maximum variance is detected). Hill's scaling (Hill and Gauch, 1980) is performed within DCA, so the length of different ordination axes is comparable for different datasets. The gradient length values show the potential to use specific ordination methods, which are based either on a model of linear species response to the underlying environmental gradient (redundancy analysis, RDA), or on a model of unimodal species response (canonical correspondence analysis, CCA) (Lepš and Šmilauer, 2000). We used the decorana () function from the package Vegan for DCA (Oksanen et al., 2013):

\section{decorana (releves),}

where releves is a dataset containing the logarithmically transformed percentage coverage of a given plant species in a given relevé. A gradient length value of 2.03 was discovered for areas along the anabranching river channel, and 1.60 for floodplain areas along the single-thread bedrockincised channel. Over a short gradient $(<3.00)$, a linear approximation works well, but over a long gradient $(>4.00)$ the approximation by the linear function is poor (Lepš and Šmilauer, 2000). A gradient length from 3.00 to 4.00 is defined as a transitional boundary between the linear and unimodal methods. From this point of view, the use of the linear method (RDA) was appropriate.

The RDA provides a model of linear species response to the underlying environmental gradient. The RDA enables the investigator to quantify the effect of known variables (in this case, the explanatory variables are distance from the main channel and relative elevation from the water level) on response variables (species composition of phytosociological relevés). We used the $r d a$ () function from the package Vegan for the RDA (Oksanen et al., 2013):

$$
\begin{aligned}
& r d a(\text { releves } \sim \text { distance }), \\
& r d a(\text { releves } \sim \text { elevation }) .
\end{aligned}
$$

The analysis of groundwater level changes helped us to detect the floodplain hydrological conditions since 1963. Only one drill well gauging station (VO 0096 - Nižní Lhoty) was available in the Morávka R. floodplain (for the location see Fig. 1). Data for groundwater levels from 1963 to 2008 were provided by the Czech Hydrometeorological Institute.

\section{Results}

The Shannon-Wiener and Simpson's indices show higher values of species diversity in the floodplain area along the naturally anabranching river channel than in the floodplain area along the single-thread bedrock-incised channel (see Tab. 1, Fig. 4). In floodplains along the anabranching channel, the mean value of the ShannonWiener index is 2.465 and the mean value of the Simpson's index is 0.901 . By contrast, in floodplains along the singlethread bedrock-incised channel, the mean value of the 
Shannon-Wiener index is 2.309 and the Simpson's index mean value is 0.887 . Median values of Shannon-Wiener and Simpson's indices are similar (Tab. 2). The two indices exhibit a very strong correlation $\left(\mathrm{r}^{2}=0.97\right)$. Though the Simpson's index is more weighted on dominant species as compared with the Shannon-Wiener index (Shannon and Weaver, 1949; Simpson, 1949), both indices demonstrate a very similar situation.

The subsequent RDA shows that the environmental variable "Distance from the main channel with flowing water" has a higher power to explain the plant species composition. In the floodplain area along the single-thread bedrock-incised channel, the plant species composition is explained by $44.46 \%(\mathrm{p}=0.008)$, and in the floodplain area along the naturally anabranching river channel pattern, the plant species composition is explained by $32.26 \%(\mathrm{p}=0.317)$. These results indicate that incision processes result in a more rapid change in the plant community composition with increasing distance from the main channel.

Similar results (but not statistically significant) were obtained for the RDA of "Relative elevation from the water level in the main channel". Relative elevation explains the

\begin{tabular}{lcccc}
\hline River-channel pattern & $\begin{array}{c}\text { Phytosociological } \\
\text { relevé }\end{array}$ & $\begin{array}{c}\text { Shannon-Wiener } \\
\text { Index }\end{array}$ & Simpson's Index & $\begin{array}{c}\text { Distance from the } \\
\text { main flow of the } \\
\text { Morávka River (m) }\end{array}$ \\
\hline $\begin{array}{l}\text { Single-thread bedrock-incised } \\
\text { channel }\end{array}$ & M1 & 2.187 & 0.873 & 62 \\
& M2 & 2.552 & 0.915 & 31 \\
& M3 & 2.378 & 0.896 & 152 \\
M4 & 2.286 & 0.888 & 217 \\
Anabranching channel & M5 & 2.140 & 0.861 & 264 \\
& S1 & 2.427 & 0.897 & 55 \\
S2 & 2.330 & 0.886 & 55 \\
\hline
\end{tabular}

Tab. 1: The Shannon-Wiener and Simpson's indices of phytosociological relevés in the study area of the Morávka River floodplain. Source: authors' calculations

\begin{tabular}{lccccc}
\hline \multirow{2}{*}{ Phytosociological relevés } & \multicolumn{2}{c}{ Arithmetic mean } & & \multicolumn{2}{c}{ Median } \\
\cline { 2 - 3 } \cline { 5 - 6 } \cline { 5 - 6 } & Shannon-Wiener Index & Simpson's Index & & Shannon-Wiener Index & Simpson's Index \\
\hline $\begin{array}{l}\text { Floodplain area of the single-thread } \\
\text { bedrock-incised channel (M1-M5) }\end{array}$ & 2.309 & 0.887 & 2.286 & 0.888 \\
$\begin{array}{l}\text { Floodplain area of the anabranching } \\
\text { channel (S1-S5) }\end{array}$ & 2.465 & 0.901 & & 2.427 & 0.897 \\
\hline
\end{tabular}

Tab. 2: Central tendency measures of the Shannon-Wiener and Simpson's indices for the analysed transects in the study area of the Morávka River floodplain. Source: authors' calculations

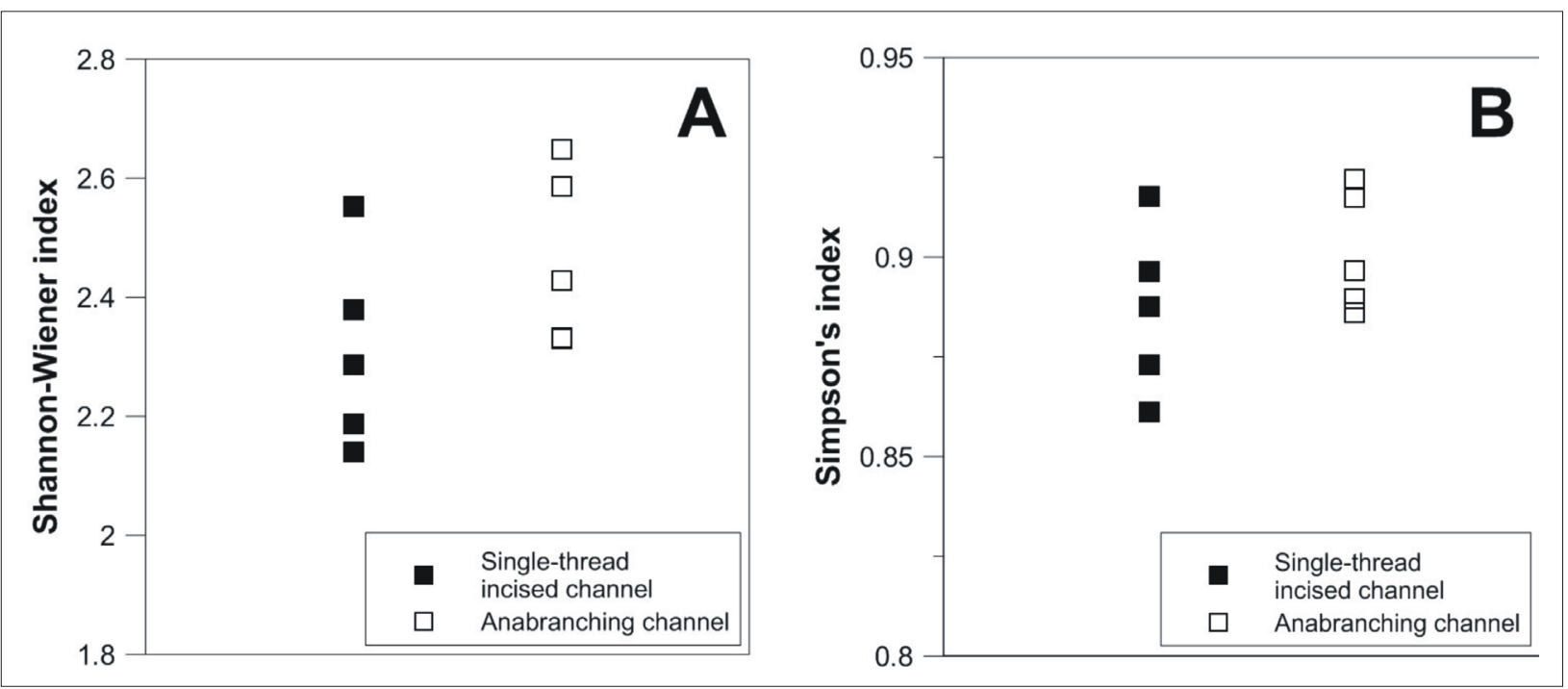

Fig. 4: A - Shannon-Wiener index and B-Simpson's index of phytosociological relevés in the study area of the Morávka River floodplain. Source: authors' elaboration 
plant species composition by $19.73 \%(\mathrm{p}=0.533)$ in the floodplain area along the single-thread bedrock-incised channel, and by $14.93 \%(\mathrm{p}=0.767)$ in the floodplain area along the naturally anabranching river channel pattern.

In addition to the above-mentioned findings, the analysis of groundwater levels revealed significant results about the changing hydrological conditions in the Morávka R. floodplain. Figure 5 shows the variation of maximum annual groundwater levels at the VO 0096 - Nižní Lhoty drill well gauging station (for the location see Fig. 1). There is a visible decreasing trend of maximum annual groundwater levels (see Fig. 5A) during the years 1963-2008: the equation of the linear trend of maximum annual water levels is $\mathrm{Y}=369.94-0.0065 \mathrm{X}\left(\mathrm{r}^{2}=0.1958, \mathrm{p}=0.0019\right)$.

\section{Discussion}

These results suggest that different plant habitat conditions occur in the incised channel reach and in the anabranching channel reach. Periodical inundation in the lower Morávka R. basin was stopped by river channel incision (Škarpich et al., 2013). Simply by comparing the Shannon-Wiener (Shannon and Weaver, 1949) and Simpson's (Simpson, 1949) indices, we can see there are differences in biodiversity between the two analysed floodplain areas. These results demonstrate a larger variety of habitat conditions in the floodplain area along the anabranching river channel. The habitat conditions are represented especially by terrestrial and semi-terrestrial habitats (sensu Hupp and Osterkamp, 1985; Hupp and Bornette, 2003), affected by periodical inundation with dry and wet periods (with terrestrial and semi-terrestrial conditions, respectively). Consequently, biodiversity is higher in the floodplain along the anabranching river channel (sensu Mikuś et al., 2013). On the other hand, the absence of floodplain periodical inundation (as along the bedrock-incised channel) leads to reduced biodiversity with plants fixed especially to terrestrial conditions.

Groundwater level is a crucial environmental factor influencing the plant species composition connected with the terrestrial and semi-terrestrial habitats $\left(\mathrm{O}^{\prime}\right.$ Brien and Currier, 1987). The logic behind using the "distance from the main channel with flowing water" and the "relative elevation from the mean water level in the main channel" as environmental variables in the RDA analysis is that the channel and the floodplain communicate together hydraulically. The water content in the floodplain decreases with increasing distance or elevation from the main channel. Comparing the floodplain areas along the two respective river patterns (anabranching channel and single-thread incised channel) we demonstrated that incision processes cause a more rapid change in the plant community composition with increasing distance from the main channel. This suggests that groundwater conditions could be affected by the river incision through the gradual relative sinking of water level in the river channel - relative to the floodplain level.

The analysis of maximum annual groundwater levels acquired from the drill well gauging station close to the anabranching river channel at the Morávka R. floodplain can be characterised by a decreasing trend (see Fig. 5A). It partially depends on the decreasing frequency and magnitude of flood discharges in the study area. The Morávka R. was characterised by high discharge variation (approximately 1:4,000 between minimal and maximal discharges; Source: Povodí Odry) before the completion of the Morávka-Žermanice Canal and the Morávka Valley Dam (Fig. 5B). The Morávka-Žermanice Canal (for the location see Fig. 1) diverts the water flow into the neighbouring Lučina River basin. After the completion of the canal in 1958, the maximum annual discharge visibly decreased (see Škarpich et al., 2013 and Fig. 5B), supported also by the functioning of a valley dam built in 1969. The interrupted trend in the maximum annual discharge in 1997 resulted from a disastrous flood in that year (the 20- to 50-year flood); the peak discharge of this flood was only slightly mitigated by the valley dam. The decreasing trend of groundwater level affects the content of water in the floodplain, which is gradually drying out.

\section{Conclusions}

We assessed the riparian vegetation and floodplain conditions in the Morávka R. study area: (i) by the statistical analysis of biodiversity indices; (ii) by RDA statistical testing

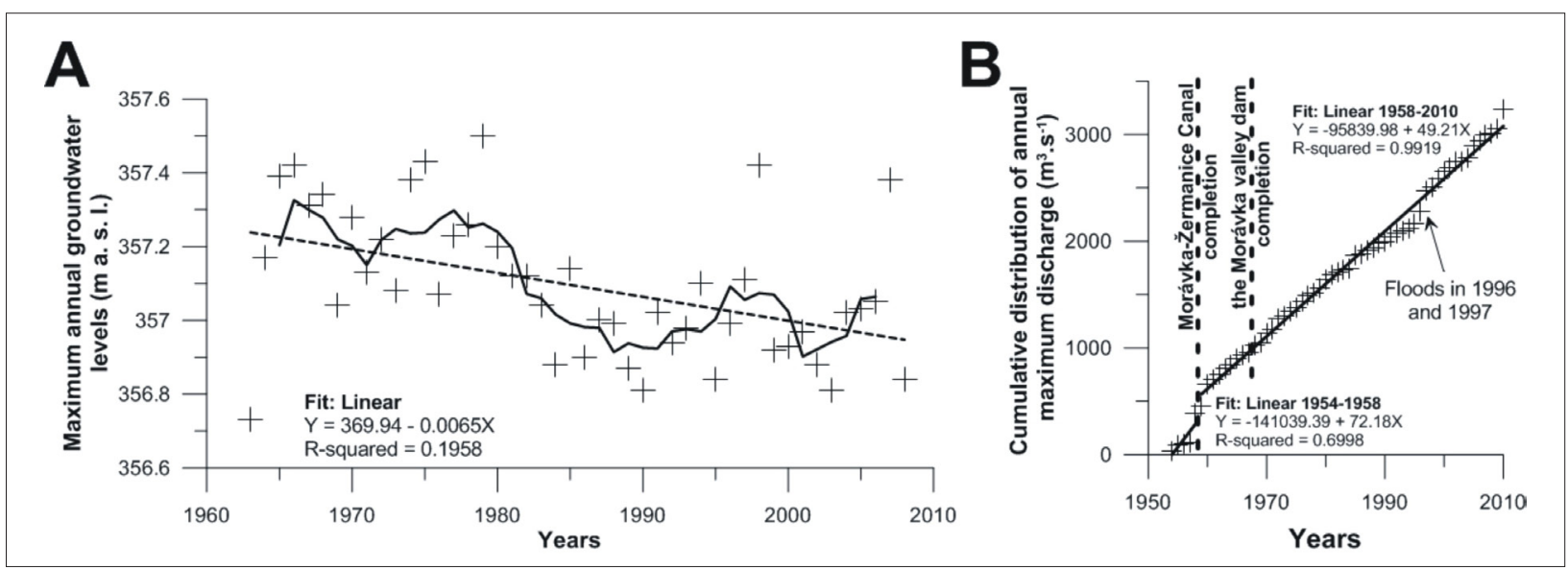

Fig. 5: A - Maximum annual groundwater levels in the years 1963-2008 at the VO 0096 - Nižni Lhoty drill well gauging station (for the location see Fig. 1)

Note: cross symbols $(+)=$ maximum annual groundwater levels, solid line = five point running mean, dashed line = linear trend); $B$ - Cumulative distribution of annual maximum discharge of the Morávka $R$. at the Raškovice gauging station (for the location see Fig. 1; cross symbols (+) = cumulative distribution of annual maximum discharge; modified from Škarpich et al., 2013)

Source: Data - Czech Hydrometeorological Institute; authors' elaboration 
of plant species composition and its dependence on distance from the main channel and relative elevation from the water level of the main channel; and (iii) by analysing the groundwater levels from the selected monitored drill well. We found that the diversity of plant species of the floodplain along the anabranching channel is higher than in the floodplain along the single-thread incised river channel. We demonstrated the dependence of plant species composition on distance from the main channel in the floodplain along the single-thread incised river channel. The plant species composition is more rapidly determined by distance from the main channel and relative elevation from the mean water level of the main channel in the floodplain area along the incised river channel. This finding refers to the changing conditions of groundwater levels affected by the incision of the river. Groundwater conditions are affected also by a generally decreasing trend of groundwater levels, and this contributes to a gradually drying out of the Morávka R. floodplain.

\section{Acknowledgements}

Preparation of this article was co-funded from the "Support for science and research in the Moravian-Silesian Region 2014" programme provided by the Moravian-Silesian Region. We would like to acknowledge both reviewers (John Jansen and an anonymous reviewer) for their valuable comments that helped to improve the manuscript quality. Thanks are extended to Aneta Krótka for her help with fieldwork and data collection.

\section{References:}

ANDERSON, M. J., ELLINGSEN, K. E., MCARDLE, B. H. (2006): Multivariate dispersion as a measure of beta diversity. Ecology Letters, 9(6): 683-693.

BROSCH, O. (2005): Povodí Odry. Anagram.

CONCENÇO, G., TOMAZI, M., CORREIA, I. V. T., SANTOS, S. A., GALON, L. (2013): Phytosociological surveys: tools for weed science? Planta Daninha, 31(2): 469-482.

CULEK, M., GRULICH, V., POVOLNÝ, D., BÍNOVÁ, L., BUCHAR, J., FALTYS, V., GAISLER, J., HROUDA, L., HUDEC, K., JEHLÍK, V., KIRCHNER, K., KRÁL, M., LACINA, J., LOŽEK, V., MACKŮ, J., MLADÝ, F., PETŘÍČEK, V., SEDLÁČKOVÁ, M., SKUHRALOVÁ, M., SOFRON, J., ŠTECH, M., TRÁVNÍČEK, B., VAŠÁTKO, J., VLAŠÍN, M., WOHLGEMUTH, E. (1996): Biogeografické členění České republiky. Praha, ENIGMA.

FORMAN R. T. T., GODRON, M. (1986): Landscape Ecology. Wiley.

GALIA, T., ŠKARPICH, V., HRADECKÝ, J., PŘIBYLA, Z. (2016): Effect of grade-control structures at various stages of their destruction on bed sediments and local channel parameters. Geomorphology 253: 305-317.

GLENN-LEWIN, D. C., PEET, R. K., VEBLEN, T. T. (1992): Plant Succession, theory and prediction. London, Chapman and Hall.

HANČINSKÝ, L. (1977): Lesnícka typológia v prevádzkovej praxi. Bratislava, Príroda.

HILL, M. O., GAUCH,H. G. (1980): Detrended correspondence analysis: an improved ordination technique. Vegetatio, 42(1-3): 47-58

HILLS, G. A. (1966): The ecological basis for land-use planning. Toronto, Dept. of Lands and Forests, Research Branch.
HUPP, C. R., BORNETTE, G. (2003): Vegetation as a tool in the interpretation of fluvial geomorphic processes and landforms in humid temperate areas. In: Kondolf, G. M., Piégay, H. [eds.]: Tools in Fluvial Geomorphology (pp. 269-288). Chichester, Wiley.

HUPP, C. R., OSTERKAMP, W. R. (1985): Bottomland vegetation distribution along Passage Creek, Virginia, in relation to fluvial landforms. Ecology, 66(3): 670-681.

KNIGHTON, D. (1998): Fluvial Forms and Processes. A new perspective. London, Arnold.

KONDOLF G. M. (1997): Hungry Water: Effects of Dams and Gravel Mining on River Channels. Environmental Management 21(4): 533-551.

KRÁLOVÁ, H. (2001): Řeky pro život, revitalizace řek a péče o nivní biotopy. Brno, ZO ČSOP Veronica.

LEPŠ, J., ŠMILAUER, P. (2000): Multivariate analysis of ecological data. České Budějovice, University of South Bohemia.

MENČÍK, E., TYRÁČEK, J. (1985): Přehledná geologická mapa Beskyd a Podbeskydské pahorkatiny, 1:100 000. Praha, Ústřední Ústav Geologický.

MENČÍK, E., ADAMOVÁ, M., DVOŘÁK, J., DUDEK, A., JETEL, J., JURKOVÁ, A., HANZLÍKOVÁ, E., HOUŠA, V., PESLOVÁ, H., RYBÁŘOVÁ, L., ŠMÍD, B., ŠEBESTA, J., TYŘÁČEK, J., VAŠÍČEK, Z. (1983): Geologie Moravskoslezských Beskyd a Podbeskydské pahorkatiny. Praha, ÚÚV v nakladatelství ČSAV.

MIKUŚ, P., WYŻGA, B., KACZKA, R. J., WALUSIAK, E, ZAWIEJSKA, J. (2013): Islands in a European mountain river: Linkages with large wood deposition, flood flows and plant diversity. Geomorphology, 202: 115-127.

NAGENDRA, H. (2002): Opposite trends in response for the Shannon and Simpson indices of landscape diversity. Applied Geography 22: 175-186.

NAIMAN, R. J., DÉCAMPS, H., MCCLAIN, M. E. (2005): Riparia. Ecology, Conservation, and Management of Streamside Communities. London, Elsevier Academic Press.

NEUHÄUSLOVÁ, Z., BLAŽKOVÁ, D., GRULICH, V., HUSOVÁ, M., CHYTRÝ, M., JENÍK, J., JIRÁSEK, J., KOLBEK, J., KROPÁČ, Z., LOŽEK, V., MORAVEC, J., PRACH, K., RYBNÍČEK, K., RYBNÍČKOVÁ, E., SÁDLO, J. (1998): Mapa potenciální přirozené vegetace České republiky, Praha, Academia.

NEUHÄUSLOVÁ, Z., MORAVEC, J., CHYTRÝ, M., LOŽEK, V., RYBNÍČEK, K., RYBNÍČKOVÁ, E., HUSOVÁ, M., GRULICH, V., JENÍK, J., SÁDLO, J., JIRÁSEK, J., KOLBEK, J., WILD J. (2001): Potential natural vegetation of the Czech Republic. BraunBlanquetia, 30: 1-80.

O'BRIEN, L. S., CURRIER, P. L. (1987): Platte River channel morphology and riparian vegetation: Changes in the Big Bend reach and minimum streamflow criteria for channel maintenance. Platte River Whooping Crane Habitat Maintenance Trust Report.

OKSANEN, J., BLANCHET, F. G., KINDT, R., LEGENDRE, P., MINCHIN, P. R., O'HARA, R. B., SIMPSON, G. L., SOLYMOS, P., STEVENS, M. H. H., WAGNER, H. (2013): Vegan (R package) [online]. [cit. 8.12.2014]. Available at URL: http://vegan.r-forge.r-project.org/ 
PICHA, F. J., STRÁNÍK, Z., KREJČÍ, O. (2006): Geology and Hydrocarbon Resources of the Outer Western Carpathians and Their Foreland, Czech Republic. In: Golonka, J., Picha, F. J. [eds.]: The Carpathians and Their Foreland: Geology and Hydrocarbon Resources (pp. 49-175). Tulsa, Oklahoma, USA, The American Association of Petroleum Geologists.

PLÍVA, K., PRŮŠA, E. (1969): Typologické podklady pěstování lesů. Praha, Státní zemědělské nakladatelství v Praze.

PRACH, K. (1994): Monitorování změn vegetace, metody a principy. Praha, Český ústav ochrany přírody.

RANDUŠKA, D., VOREL, J., PLÍVA, K. (1986): Fytocenológia a lesnická typológia. Bratislava, Príroda.

R CORE TEAM (2012): R: A language and environment for statistical computing [online]. Vienna, Austria, R Foundation for Statistical Computing. [cit. 8.12.2014] Available at: URL: http://www.R-project.org/

SCHÖNHAR, S. (1993). Die Waldbodenvegetation als Standortsweiser. Allg. Forstund Jagdzeitung, 164: 173-180.

SHANNON, C. E, WEAVER, W. (1949): The Mathematical Theory of Communication. Urbana, USA, University of Illinois Press.

SIMPSON, E. H. (1949): Measurement of diversity. Nature, 163: 688.

SOLON, J., DEGÓRSKI, M., ROO-ZIELIŃSKA, E. (2007): Vegetation response to a topographical-soil gradient. Catena, 71: 309-320.
STEIGER, J., TABACCHI, E., DUFOUR, S., CORENBLIT, D., PEIRY, J. L. (2005): Hydrogeomorphic processes affecting riparian habitat within alluvial channel-floodplain river systems: a review for the temperate zone. River Research and Application, 21(7): 719-737.

ŠEFFER, J., STANOVÁ, V. (1999): Aluviálne lúky rieky Moravy - význam, obnova a manažment (Morava river floodplain Meadows - Importance, Restoration and Management). Bratislava, DAPHNE - Centrum pre aplikovanú ekológiu.

ŠKARPICH, V., HRADECKÝ, J., DUŠEK, R. (2013): Complex transformation of the geomorphic régime of channels in the forefield of the Moravskoslezské Beskydy Mts.: Case study of the Morávka River (Czech Republic). Catena, 111: 25-40.

ŠKARPICH, V., KAŠPÁREK, Z., GALIA, T., HRADECKÝ, J. (2016): Antropogenní impakt a jeho odezva v morfologii koryt beskydských štěrkonosných toků: příkladová studie řeky Ostravice, Česko. Geografie 121(1): 99-120.

TABACCHI, E., CORRELL, D., HAUER, R., PINAY, G., PLANTY-TABACCHI, A. M., WISSMAR, R. C. (1998): Development, maintenance and role of riparian vegetation in the river landscape. Freshwater Biology, 40(3): 497-516.

WALKER, L. R., DEL MORAL, R. (2003): Primary Succession and Ecosystem Rehabilitation. Cambridge, USA, Cambridge University Press.

XIAO, D. N., LI, X. Z., GAO, J., CHANG, Y., LI, T. S. (2003): Landscape Ecology. Beijing, Science Press.

Please cite this article as:

ŠKARPICH, V., HORÁČEK, M., GALIA, T., KAPUSTOVÁ, V., ŠALA, V. (2016): The effects of river patterns on riparian vegetation: A comparison of anabranching and single-thread incised channels. Moravian Geographical Reports, 24(3): 24-31. Doi: 10.1515/mgr-2016-0014. 